\title{
Upgrading photolysis in the p-TOMCAT CTM: model evaluation and assessment of the role of clouds
}

\author{
A. Voulgarakis ${ }^{1, *}$, N. H. Savage ${ }^{2}$, O. Wild ${ }^{3}$, G. D. Carver ${ }^{1}$, K. C. Clemitshaw ${ }^{4}$, and J. A. Pyle ${ }^{1}$ \\ ${ }^{1}$ Centre for Atmospheric Science, University of Cambridge, Cambridge, UK \\ ${ }^{2}$ Met Office, Exeter, UK \\ ${ }^{3}$ Lancaster Environment Centre, University of Lancaster, Lancaster, UK \\ ${ }^{4}$ Department of Earth Sciences, Royal Holloway, University of London, London, UK \\ * now at: Columbia University, Center for Climate Systems Research, NASA Goddard Institute for Space Studies, \\ New York, USA
}

Received: 22 October 2008 - Published in Geosci. Model Dev. Discuss.: 27 November 2008

Revised: 5 May 2009 - Accepted: 8 May 2009 - Published: 20 May 2009

\begin{abstract}
A new version of the p-TOMCAT Chemical Transport Model (CTM) which includes an improved photolysis code, Fast-JX, is validated. Through offline testing we show that Fast-JX captures well the observed $J\left(\mathrm{NO}_{2}\right)$ and $J\left(\mathrm{O}^{1} \mathrm{D}\right)$ values obtained at Weybourne and during a flight above the Atlantic, though with some overestimation of $J\left(\mathrm{O}^{1} \mathrm{D}\right)$ when comparing to the aircraft data. By comparing p-TOMCAT output of $\mathrm{CO}$ and ozone with measurements, we find that the inclusion of Fast-JX in the CTM strongly improves the latter's ability to capture the seasonality and levels of tracers' concentrations. A probability distribution analysis demonstrates that photolysis rates and oxidant $(\mathrm{OH}$, ozone) concentrations cover a broader range of values when using Fast-JX instead of the standard photolysis scheme. This is not only driven by improvements in the seasonality of cloudiness but also even more by the better representation of cloud spatial variability. We use three different cloud treatments to study the radiative effect of clouds on the abundances of a range of tracers and find only modest effects on a global scale. This is consistent with the most relevant recent study. The new version of the validated CTM will be used for a variety of future studies examining the variability of tropospheric composition and its drivers.
\end{abstract}

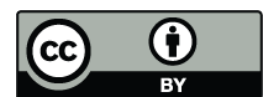

Correspondence to: A. Voulgarakis (avoulgarakis@giss.nasa.gov)

\section{Introduction}

Photodissociation of trace gases is among the most important processes determining tropospheric composition. For this reason, Chemical Transport Models (CTMs) need to simulate radiative transfer in the atmosphere in an accurate way. Clouds are among the major factors modifying radiation and research has shown that in order to fully evaluate photolysis calculations, performance under cloudy sky conditions must be examined (Madronich, 1987; Matthijsen et al., 1998; Liao et al., 1999; Crawford et al., 2003; Lefer et al., 2003; Yang and Levy, 2004; Monks et al., 2004). The decrease of radiation below the clouds (attenuation) and the increase at the clouds' upper parts and above (because of backscatter), cause a significant redistribution of the actinic flux available for photolysis.

Accurate simulation of multiple scattering in the UV and visible parts of the spectrum $(180-800 \mathrm{~nm})$ is not a recent scientific advance (e.g. Chandrasekhar, 1960), nor is the inclusion of such calculations in atmospheric models (e.g. Liao et al., 1999). However, these detailed radiative transfer models were always too expensive for use in global chemical transport models, because of the large number of grid points and the long simulation times required, as well as the extra computational power needed for detailed chemistry integrations. This is the main reason why most of the latter have employed a restrictive two-stream approximation (e.g. Hough, 1988; Roelofs and Lelieveld, 1995), where light is only assumed to be transmitted forwards and backwards. Many efforts have been made to improve the two-stream approach

Published by Copernicus Publications on behalf of the European Geosciences Union. 
(e.g. by scaling) but the results were generally weak, either in terms of accuracy or in terms of efficiency.

A new generation of photolysis codes (Fast-J (Wild et al., 2000), Fast-TUV (Tie et al., 2003b)) which emerged some years ago, has made the online calculation of photolysis rates affordable in global models. The latest version of Fast-J, Fast-JX, has been implemented in the Cambridge pTOMCAT tropospheric CTM in this study.

Wild et al. (2000) performed tests on the Fast-J photolysis rate output, by comparing calculated values with those computed using two other parameterized cloud/photolysis schemes. They found that Fast-J provided a more consistent simulation of cloud effects. Barnard et al. (2004) evaluated Fast-J $J\left(\mathrm{NO}_{2}\right)$ values against measurements and found reasonably good agreement. The online chemistry results presented in the original Fast-J paper demonstrated that there are major advantages in using Fast-J, especially when clouds with large vertical extent or multiple cloud/aerosol layers are present. However, they did not validate the improvements of global model performance against measurements.

In this paper, we evaluate the performance of the pTOMCAT CTM with and without Fast-JX and its ability to simulate the effect of clouds on photolysis rates and photochemistry in general. A set of photolysis rates and tracer measurements has been used for this purpose. This assessment can also serve as a reference for future work using this updated model version. More specifically, in Sect. 2 we describe the basic features of the model, followed by an offline evaluation of photolysis code performance in Sect. 3. The validation of the CTM using the upgraded photolysis scheme is presented in Sect. 4. Finally, a summary and conclusions are included in Sect. 5.

\section{Model description}

\subsection{Cambridge p-TOMCAT CTM}

The global tropospheric model p-TOMCAT is a three dimensional CTM derived from the original TOMCAT model initially described by Law et al. (1998). The model has 31 levels from the ground up to $10 \mathrm{hPa}$ extending to the stratosphere, although it is mainly a tropospheric CTM. The resolution used in this study is $2.8^{\circ} \times 2.8^{\circ}$ (T42). The CTM takes 63 chemical species into account, of which 41 are advected, and it includes 37 photolysis, 119 bimolecular and 16 termolecular reactions. Chemistry is simulated using the atmospheric chemistry integration package ASAD (Carver et al., 1997) and is integrated with the IMPACT scheme (Carver and Stott, 1999). For the purposes of this study, we adopted a reduced isoprene mechanism based on Pöschl et al. (2000), as implemented by Young et al. (2008). The reaction rates for all species were updated in March 2005 according to the latest IUPAC (Atkinson et al., 2005) and other published rates. We also include the heterogeneous removal of $\mathrm{N}_{2} \mathrm{O}_{5}$ on sul- fate aerosol following the method in the MOZART model (Tie et al., 2003a), with the addition of a more detailed calculation of the uptake coefficient based on Evans and Jacob (2005). Offline monthly mean aerosols were taken from the GOCART model output (Chin et al., 2002) to be used as input for this calculation.

The tracer advection of the model is based on the use of the second order moment scheme of Prather (1986) forced with six-hourly meteorological analysis data from the ECMWF, which provides input for winds, temperature, pressure and humidity. Moist convection transport is performed using the mass flux scheme of Tiedtke (1989) and a non-local vertical diffusion scheme (PBL) is used based on that developed for the NCAR Community Climate Models, Version 2 (Holtslag and Boville, 1993) and implemented as described by Wang et al. (1999). The wet and dry deposition schemes and their validation are described in Giannakopoulos et al. (1999).

For the purposes of this project, we have used annually and monthly varying emissions for industry, transport, shipping and biomass burning from the RETRO emissions database (Schultz, 2007b). Schultz et al. (2008) describe biomass burning emissions specifically and Pulles and van het Bolscher (2007) include information about the terrestrial anthropogenic emissions produced using the TNO Emission Assessment Model (TEAM). Biogenic emissions are either taken from Müller (1992) or from Lathière et al. (2006) depending on the species. Lightning emissions of $\mathrm{NO}_{\mathrm{x}}$ are based on the parameterization of Price and Rind (1994) as implemented by Stockwell et al. (1999). The average lightning emissions for the 1996-2000 period is set to $3.9 \mathrm{Tg}(\mathrm{N}) \mathrm{yr}^{-1}$. Methane has been fixed to a global annual 3-D field produced from an earlier long-term integration (global burden is $4760 \mathrm{Tg}$ methane). We have recently found that this methane field is too low to represent a contemporary atmosphere. The field now adopted (but not used in this study) has a higher global mean methane concentration $(1760 \mathrm{ppb})$ as is the case for other standard model studies (e.g. Stevenson et al., 2006). At the upper boundary, ozone, methane and $\mathrm{NO}_{\mathrm{y}}$ are prescribed with climatological values from the Cambridge 2D-Model (Law and Pyle, 1993). We note that the ECMWF re-analysis data that have been used to drive the model have been found to produce a too strong stratospheric circulation and a significantly overestimated stratosphere-troposphere exchange (Uppala et al., 2005). This is something that may drive biases in modelled upper tropospheric ozone.

\subsection{Standard photolysis treatment in p-TOMCAT}

The standard p-TOMCAT model version uses photolysis rates calculated offline by the Cambridge 2D-Model (Law and Pyle, 1993). The scheme which is used to calculate the photolysis rates in the 2D-model is the two-stream method of Hough (1988). It takes account of multiple scattering by clouds using a climatological cloud cover dataset. 2-D 

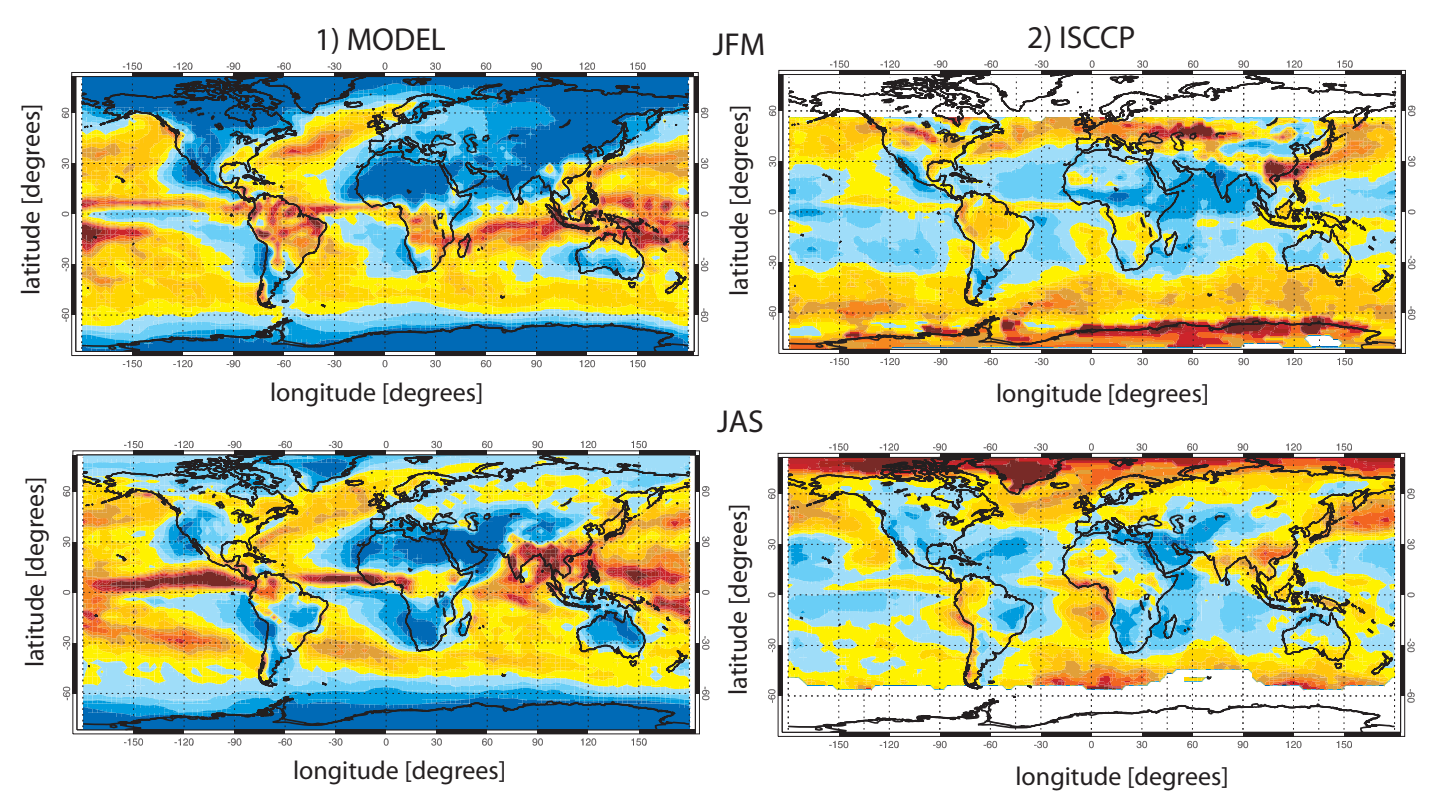

JAS
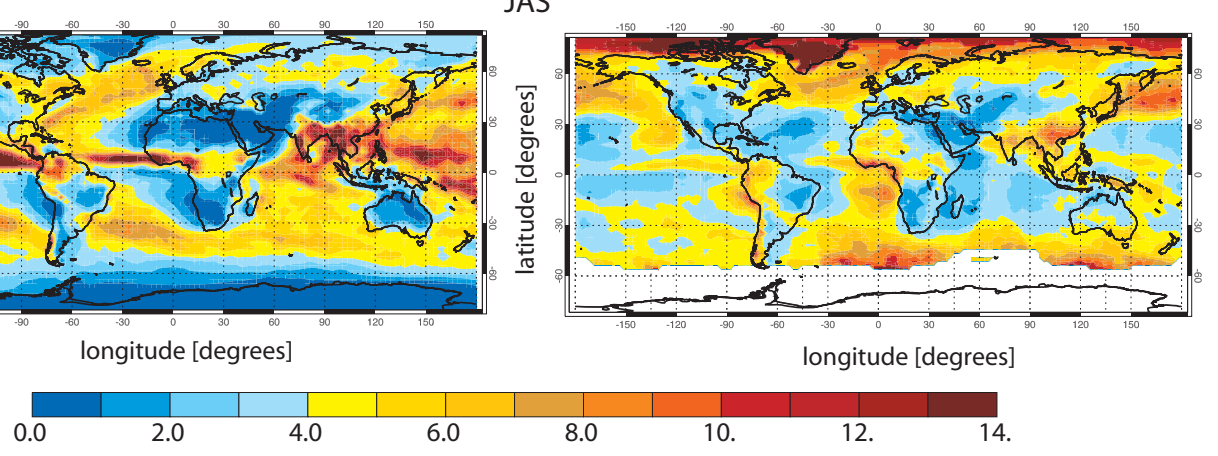

Fig. 1. Total cloud optical depths (integrated from the surface to top of the atmosphere) calculated from the ECMWF fields compared to ISCCP values. Top two panels are for January-February-March (JFM) and bottom two for July-August-September (JAS). Left two panels are model values and the right are ISCCP.

photolysis rates are interpolated at three fixed times as a function of the solar zenith angle.

Generally, the steps followed during the performance of the standard p-TOMCAT photolysis scheme are: (1) read in 2-D photolysis data; (2) interpolate each photolysis rate from the 2-D latitudes and levels on to p-TOMCAT latitudes and levels; (3) interpolate the three diurnal values of the photolysis rates in time of day to the local time for each p-TOMCAT grid point. This photolysis scheme's main drawback is that it has a poor handling of clouds, since only a zonally and seasonally averaged cloudiness is taken into account. The twodimensional, offline nature of this algorithm makes it out-ofdate with present-day model developments.

\subsection{Fast-J and Fast-JX}

The Fast-J algorithm is a numerical routine which was built to calculate photolysis rates in a fast and accurate way, under both clear and cloudy sky conditions. Two of the main advantages of Fast-J are the optimization of the phase function expansion and the optimization of the integration over wavelength (described in Wild et al. (2000)). In Fast-JX (Neu et al., 2007), an improved version of the original Fast-J code, the scattering calculations are extended to the stratosphere and lower mesosphere (up to $60 \mathrm{~km}$ ). Also, there are changes in the way that optically thick clouds are treated and updates in the solar flux and cross-section datasets used.
The photolysis code used for this project is Fast-JX. Threedimensional gridbox-averaged six-hourly cloud liquid/ice water contents, cloud fractions and surface albedos come from the ECMWF analyses. Temperatures and pressures are also read-in from the ECMWF analyses. The monthly-mean background ozone climatology supplied with Fast-J is used. No aerosols have been considered in the radiative transfer calculations for simplicity. Cloud optical depths are calculated using the method described by Slingo and Schrecker (1982), in its extended form as described by (Del Genio et al., 1996) to account for ice-clouds as well as liquid clouds:

$\tau=3 \frac{W C}{2 r_{e}} d z$

where $\tau$ is the cloud optical depth, $W C$ is the water content $\left(\mathrm{g} / \mathrm{m}^{3}\right), d z$ is the thickness of the cloud layer $(\mathrm{m})$ and $r_{e}$ is the effective radius for cloud water droplets $(\mu \mathrm{m})$. The effective radius does not depend on water content, but is parameterized the same way as in the ECMWF IFS (Integrated Forecasting System) model (2004 version): for liquid clouds it is a linear function of height from $10 \mu \mathrm{m}$ at the surface to $45 \mu \mathrm{m}$ at the top of the atmosphere, and for ice clouds it is fixed to $40 \mu \mathrm{m}$.

Another issue to consider is the way that multiple cloud layers are assumed to overlap with each other. The simplest way of dealing with this in chemistry models is to assume that clouds cover the entire horizontal grid and the cloud optical depth is linearly averaged over the clear and cloudy areas in each layer (LIN method). If this method is used, the 

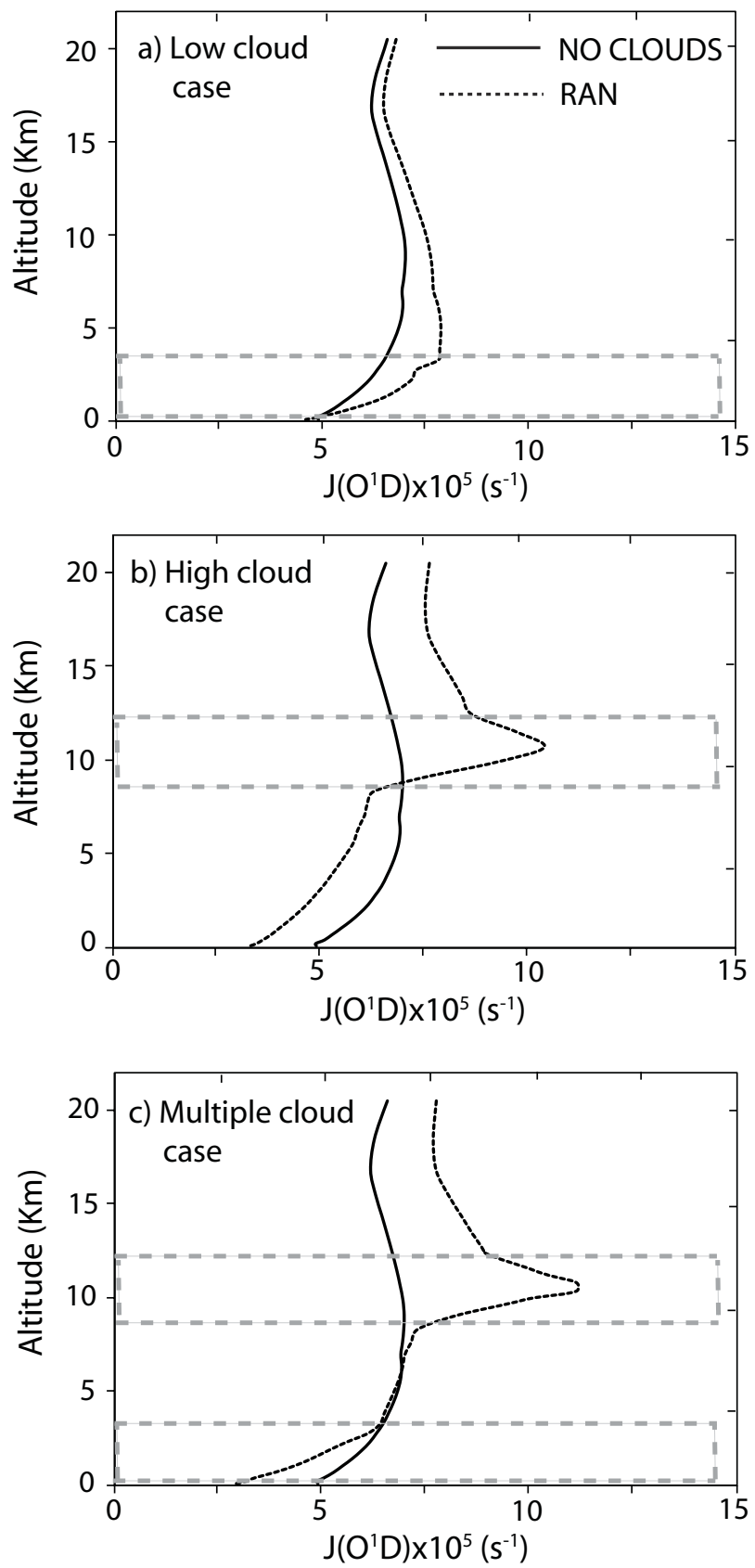

Fig. 2. One-dimensional test for the offline examination of the effect of clouds on $J\left(\mathrm{O}^{1} \mathrm{D}\right)$. Three cases for $0^{\circ} \mathrm{N}$ are shown: (a) low cloud $(0-3 \mathrm{~km})$, (b) high cloud (9-12 km) and (c) multiple cloud (0-3 km and $9-12 \mathrm{~km})$.

in-cloud optical depth has to be scaled by the cloud fraction. However, in this study, the cloud optical depth has been calculated by water content data which were already given as gridbox averages and not as in-cloud values, thus this scaling is not needed for LIN. The other option used is the approximate random overlap method (referred to as RAN). In a random overlap scheme, clouds in overlying layers are in- dependent and randomly overlapped. This method requires a large, computationally expensive set of calculations. However, Briegleb (1992) have shown that one can approximate random overlap to calculate heating rates (and, as shown by Feng et al. (2004), to a satisfactory level the photochemical effects of overlap) with the following formula:

$\tau_{c}^{\prime}=\tau_{c} f^{3 / 2}$

where $f$ is the cloud fraction, $\tau_{c}$ is the initial optical depth and $\tau_{c}^{\prime}$ is the new optical depth after accounting for the overlap. In this study, we use the gridbox average optical depth which is calculated by the Slingo and Schrecker equation (different to the in-cloud optical depths that other published studies have used (Tie et al., 2003b; Liu et al., 2006a)) divided by the fraction $f$ to get the in-cloud optical depth and then multiplied by $f^{3 / 2}$ to simulate the overlap. So, the overall multiplication factor is $f^{1 / 2}$.

According to Liu et al. (2006a) this approximate version of RAN is a good approximation so that the overlap of clouds is taken into account and is much more computationally efficient than MRAN, the maximum-random overlap method which assumes that clouds in adjacent model layers are maximally overlapped and form blocks. To conclude, approximate RAN is the method that combines well accuracy and efficiency, and is the standard method used in Fast-JX to handle clouds for the purposes of this study.

The optical depths calculated for winter and summer are compared to ISCCP values in Fig. 1. The comparison shows that the modelled values capture well the cloudiness associated with the northern extratropical cyclonic activity (Atlantic and Pacific). The Southern Hemisphere extratropical marine stratus cloud position is also captured in a satisfactory way. However, as was the case for other studies (Tie et al., 2003b; Liu et al., 2006a), the tropical cloudiness associated with convection is greatly overestimated. Discrepancies at very high latitudes mostly have to do with problems of the satellite retrievals due to surface albedo effects.

A final thing to note related to the model set-up, is that for many of the isoprene-related species, we calculated new cross-section data needed to allow their photolysis reactions to be taken into account. For that purpose the latest IUPAC data were reapportioned to the Fast-JX wavelength bins.

In the following section we validate the Fast-JX photolysis code offline (Sect. 3), followed by the overall evaluation of the updated version of p-TOMCAT using this photolysis code.

\section{Offline photolysis code testing}

\subsection{One dimensional tests}

The first offline (standalone) test performed with Fast-JX examines how well the model captures the vertical variations in 


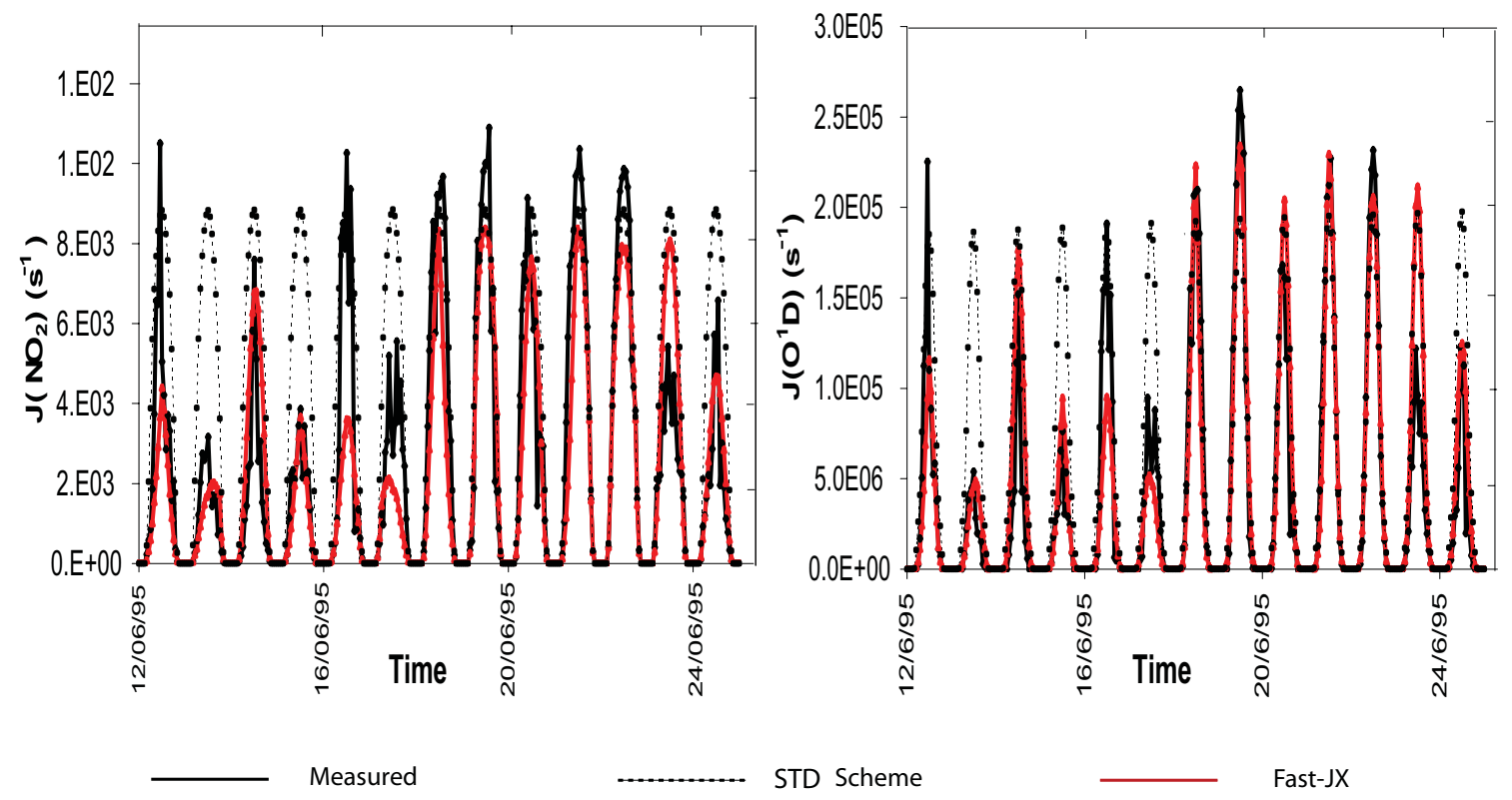

Fig. 3. Comparison of modelled $J\left(\mathrm{NO}_{2}\right)$ and $J\left(\mathrm{O}^{1} \mathrm{D}\right)$ values (Fast-JX and standard scheme) to observations from Weybourne $\left(52.9^{\circ} \mathrm{N}, 1.1^{\circ} \mathrm{E}\right)$ for June 1995. A surface albedo of 0.05 is used (in contrast to 0.1 in Fig. 2). No aerosols are included and the monthly-mean background ozone climatology supplied with Fast-J is used.

photolytic activity in the presence of clouds. The cases examined are those presented in Fig. 7a of Liu et al. (2006b), in a similar way with what was done by Tie et al. (2003b) (Fig. 12) using the FTUV photolysis code.

In Fig. 2, the thick solid line represents the case where no clouds are taken into account and the thin dotted line represents the cloudy cases. The $J\left(\mathrm{O}^{1} \mathrm{D}\right)$ results are for $0^{\circ} \mathrm{N}$ atmospheric conditions and overhead sun. Surface albedo is assumed to be 0.1 and no aerosols are taken into account. The total ozone column is set to 300 DU. In the first case (a) a cloud layer is placed at the model levels between 0 and $3 \mathrm{~km}$. The second case (b) assumes that the single cloud layer exists between 9 and $12 \mathrm{~km}$ and finally in the third case (c), multilayer clouds are placed between $0-3 \mathrm{~km}$ and $9-12 \mathrm{~km}$. In all cases, the cloud liquid water content is $0.1 \mathrm{~g} / \mathrm{m}^{3}$, the cloud fraction is set to 0.50 for all cloudy gridboxes and the RAN method is used to simulate cloud overlap, as the best option available in our implementation.

The results are comparable with the results of Tie et al. (2003b) (FTUV) and very similar to Liu et al. (2006a) (Fast$\mathrm{J})$ : For the low-cloud case $(\mathrm{a}), J\left(\mathrm{O}^{1} \mathrm{D}\right)$ increases above and throughout most of the cloud. The maximum enhancement (20\%) occurs at the top of the cloud layer. When the cloud layer is placed high in the troposphere, photolysis rate enhancements occur above and throughout most of the cloud's vertical extent, and significant reductions occur below the cloud. The increase at the top of the cloud layer is $52 \%$ and the reduction at the Earth's surface is $32 \%$. For the multiple cloud layer case, the above-cloud enhancement of $J\left(\mathrm{O}^{1} \mathrm{D}\right)$ is even more pronounced (58\%) compared to the single-cloud cases and the reduction of $J\left(\mathrm{O}^{1} \mathrm{D}\right)$ below the high cloud is smaller. Both of these features are attributed to the internal reflections of radiation occurring between the two layers of clouds. The photolysis rates at the surface for this case are the lowest ( $41 \%$ reduction compared to clear-sky), since the overall effect of two cloud layers is stronger than that of a single one, as expected.

\subsection{Comparison to measurements}

The next step was to compare the Fast-JX photolysis rates to measurements. Comparisons of Fast-J results to measurements have been shown in the past (Barnard et al., 2004), but only for $J\left(\mathrm{NO}_{2}\right)$ and only for the surface. Here, we assess $J\left(\mathrm{O}^{1} \mathrm{D}\right)$ results as well and use both surface observations (from the Weybourne Atmospheric Observatory Summer Experiment - WAOSE'95) and aircraft measurements (from a flight which was part of the ACSOE experiment in 1997).

Cloud water content, temperature and pressure data come from the ECMWF operational analyses (extracted from the same dataset later used for the CTM runs) and the surface albedo is set to be 0.05 , a representative value for marine locations with no ice. No aerosols are included in these runs. The total ozone column is taken from the climatology supplied by Fast-JX.

In Fig. 3, measured $J\left(\mathrm{NO}_{2}\right)$ and $J\left(\mathrm{O}^{1} \mathrm{D}\right)$ values are represented by the thick black line and Fast-JX calculated values are represented by the red line. The results from the offline calculations using the standard photolysis scheme are depicted with the dotted black line. 

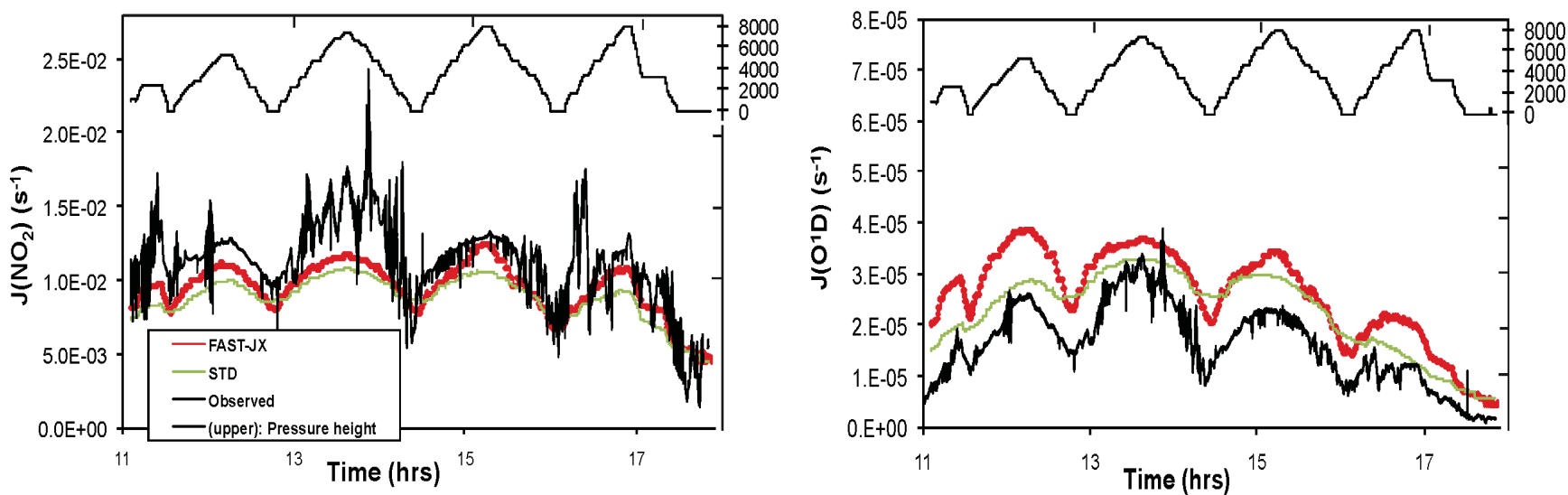

Fig. 4. Comparison of modelled $J\left(\mathrm{NO}_{2}\right)$ and $J\left(\mathrm{O}^{1} \mathrm{D}\right)$ values (Fast-JX and standard scheme) to aircraft observations (ACSOE) for September 1997. Surface albedo is 0.05 , no aerosols are included and the monthly-mean background ozone climatology supplied with Fast-J is used.
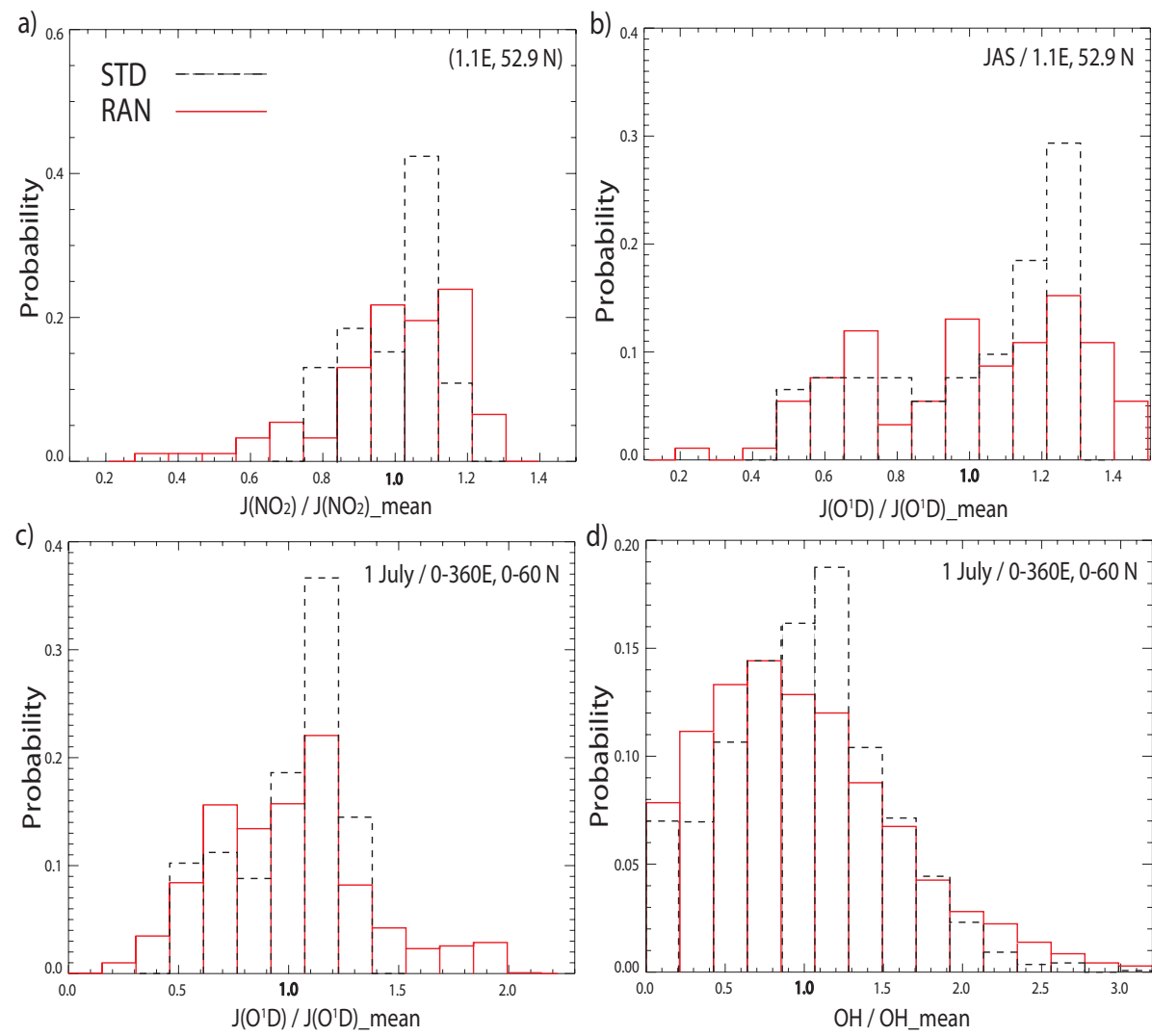

Fig. 5. Probability Distribution Function (PDF) normalized to the mean value for (a) calculated $J\left(\mathrm{NO}_{2}\right)$ at Weybourne (July-AugustSeptember), (b) calculated $J\left(\mathrm{O}^{1} \mathrm{D}\right)$ at Weybourne (JAS), (c) $J\left(\mathrm{O}^{1} \mathrm{D}\right)$ at 0-60 N (1st of July) and (d) OH at 0-60 N (1 st of July).

As mentioned before, the latter scheme interpolates tabulated photolysis rates calculated offline using a climatological cloud field. For Weybourne $\left(1.1^{\circ} \mathrm{E}, 52.9^{\circ} \mathrm{N}\right)$, it is clear that this cannot reproduce the day-to-day varying features of $J\left(\mathrm{NO}_{2}\right)$ and $J\left(\mathrm{O}^{1} \mathrm{D}\right)$, and the calculated photolysis rates peak every day at almost the same value. Fast-JX successfully captures the decrease in photolysis rates in days with significant cloudiness and reduced photolytic activity $(13 / 06,14 / 06,15 / 06,17 / 06,24 / 06)$. A day with a substantial difference between the output of Fast-JX and the measurements $(16 / 06)$ may be a result of discrepancies between the ECMWF cloud data and the actual cloudiness at the time of the observations. 
Overall, the performance of Fast-JX for Weybourne is good, with an average relative bias of $-14 \%$ for $J\left(\mathrm{NO}_{2}\right)$ $\left(+54 \%\right.$ with the standard scheme) and $+23 \%$ for $J\left(\mathrm{O}^{1} \mathrm{D}\right)$ (+46\% with the standard scheme).

In Fig. 4, the same variables are shown for an ACSOE flight which took place on the 20/09/97 $\left(22.0^{\circ} \mathrm{W}-29.9^{\circ} \mathrm{W}\right.$, $\left.37.0^{\circ} \mathrm{N}-44.1^{\circ} \mathrm{N}\right)$. The dashed line at the top shows the altitude of the aircraft. For both $J\left(\mathrm{NO}_{2}\right)$ and $J\left(\mathrm{O}^{1} \mathrm{D}\right)$ FastJX captures the variability of photolysis rates well, while the standard code shows much less variability than the measurements. This can again be attributed to the better representation of clouds in Fast-JX than in the standard scheme, as well as to the differences in the way that cloud scattering is simulated by the two codes. The two-stream approximation used in the Cambridge 2D-Model for the production of the photolysis look-up tables used in the standard treatment assumes isotropic scattering and no angular dependence, making it an approximate approach by definition. Another possible cause of changes in variability between the two codes is the better representation of the temperature dependence of photolysis rates in Fast-JX (cross sections and quantum yields), an important factor especially for $J\left(\mathrm{O}^{1} \mathrm{D}\right)$.

Fast-JX does very well in capturing the variability with height and time, but its results are significantly higher than the aircraft measurements for $J\left(\mathrm{O}^{1} \mathrm{D}\right)$. An over-estimation of $J\left(\mathrm{O}^{1} \mathrm{D}\right)$ for most of the troposphere was found by Tie et al. (2003b) when examining the differences between TUV (code with 140 wavelength bins) and FTUV (fast code with 17 wavelength bins). This was not the case when comparing the standard UCI photolysis code (40 bins) to the initial Fast-J version (7 bins), which is similar to Fast-JX (see Appendix C of Wild et al. (2000)). However, a comparison of $J\left(\mathrm{O}^{1} \mathrm{D}\right)$ values to measurements for any of the Fast-J versions had not so far been reported in the literature. An issue which should also be considered is the quality of the measurements. According to Volz-Thomas et al. (1996), the estimated accuracy of the $J\left(\mathrm{NO}_{2}\right)$ measurements is $8 \%$, including cases of cloudy conditions, low sun, or when the aircraft is inclined during turns. The authors do not assess $J\left(\mathrm{O}^{1} \mathrm{D}\right)$ measurements, which are known to involve larger uncertainties (Bohn et al., 2008). This suggests that part of the discrepancies found between the model and the measurements may be caused by weaknesses of the latter.

In general, Fast-JX captures much of the variability of photolysis rates well and reproduces values successfully for Weybourne (both $J\left(\mathrm{NO}_{2}\right)$ and $J\left(\mathrm{O}^{1} \mathrm{D}\right)$ ). There are discrepancies between modelled and observed values for $J\left(\mathrm{O}^{1} \mathrm{D}\right)$ higher up (ACSOE flight) but this does not offset the advantages gained by the use of such a detailed photolysis code in the CTM.

\section{Evaluation of p-TOMCAT using Fast-JX}

In order to validate the CTM's overall performance, it was run for 15 months (October 1996 to December 1997), 3 of which were for spin-up. The main experimental runs were: (a) a run using the standard photolysis scheme (tagged as STD) and (b) the run using Fast-JX (tagged as RAN as it uses the approximate random overlap assumption).

\subsection{Ability to capture temporal and spatial variations}

The inclusion of a state-of-the-art photolysis scheme, which has the ability to include clouds with a six-hourly and threedimensional variation, should allow the CTM to capture the spatial and temporal distribution of photolysis rates and the concentration of related chemical species more accurately. To examine this advantage of the model, we first plotted (Fig. 5) the probability distribution function (PDF) for $J\left(\mathrm{NO}_{2}\right)$ and $J\left(\mathrm{O}^{1} \mathrm{D}\right)$ as calculated by the CTM, normalized to the corresponding mean values. This was done for the location of Weybourne $\left(1.1^{\circ} \mathrm{E}, 52.9^{\circ} \mathrm{N}\right)$ (upper two panels) which was also used earlier in this study. The period of July-August-September (JAS) 1997 was selected, during which cloudiness is expected to show substantial variability. Only noon values were sampled (92 values in total), in order to have a clearer signal.

For both $J\left(\mathrm{NO}_{2}\right)$ and $J\left(\mathrm{O}^{1} \mathrm{D}\right)$, the distribution of values is broader when using the updated version of p-TOMCAT with Fast-JX, as opposed to when using the standard photolysis scheme. For both variables, there is a strong peak slightly higher than the mean, and then the values of the new model version extend to more bins than the standard version. A significant factor making noon photolysis rates variable during the period examined is the changes in the solar zenith angle, which increases between July and September. For this reason, equivalent plots for a location on the equator have a much narrower distribution (not shown). However, this factor is not the cause of the differences between the standard and the new scheme, as it applies to both.

In the bottom two panels, the normalized PDFs for $J\left(\mathrm{O}^{1} \mathrm{D}\right)$ and $\mathrm{OH}$ are shown for latitudes between $0^{\circ}-60^{\circ} \mathrm{N}$ and for the 1st of July only (2816 values in total; this number is equal to the grid-points used for this day). This plot provides information on how the spatial distribution of the two variables is affected by the choice of photolysis treatment. High latitudes are not taken into account as they will have low photolysis frequencies and may again weaken the signal. It is clear that for $J\left(\mathrm{O}^{1} \mathrm{D}\right)$ the range of output values of the new version of the model is much broader than that of the standard version. For $\mathrm{OH}$, this feature is less strong but still present: there are values in all bins for both model versions, but those closer to the mean are more frequent in the standard version, while those with the largest departure from the mean are more common in the new. 

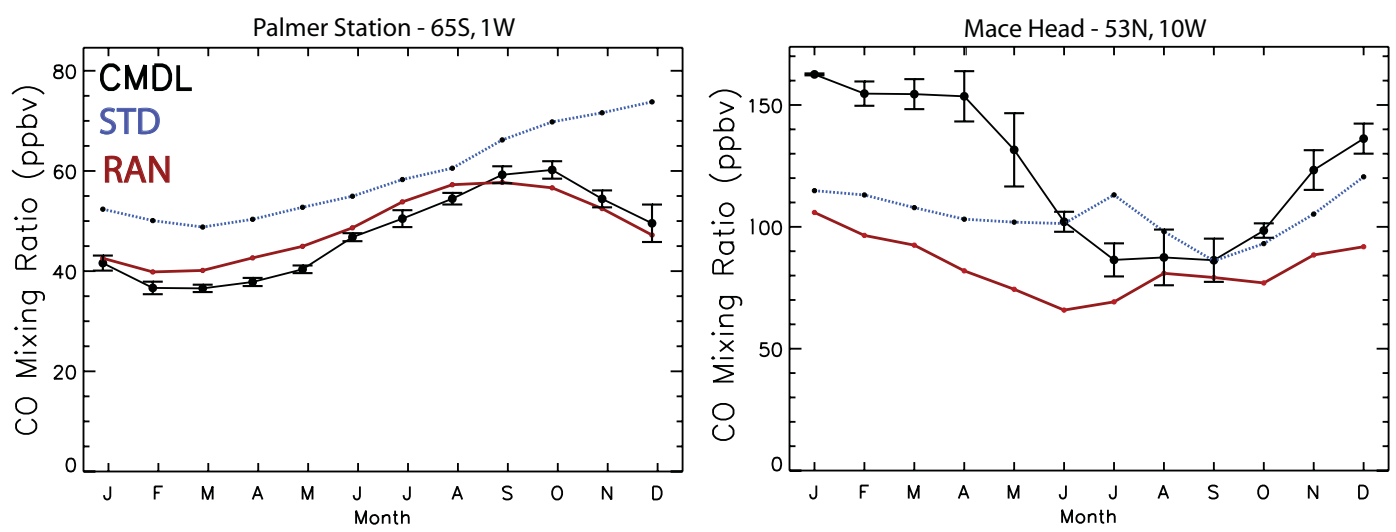

Fig. 6. CO model (STD and RAN) - measurement (CMDL) comparisons for Mace Head (MHD) and Palmer Station (PSA). Error bars indicate the temporal variability of measurements made within each month.
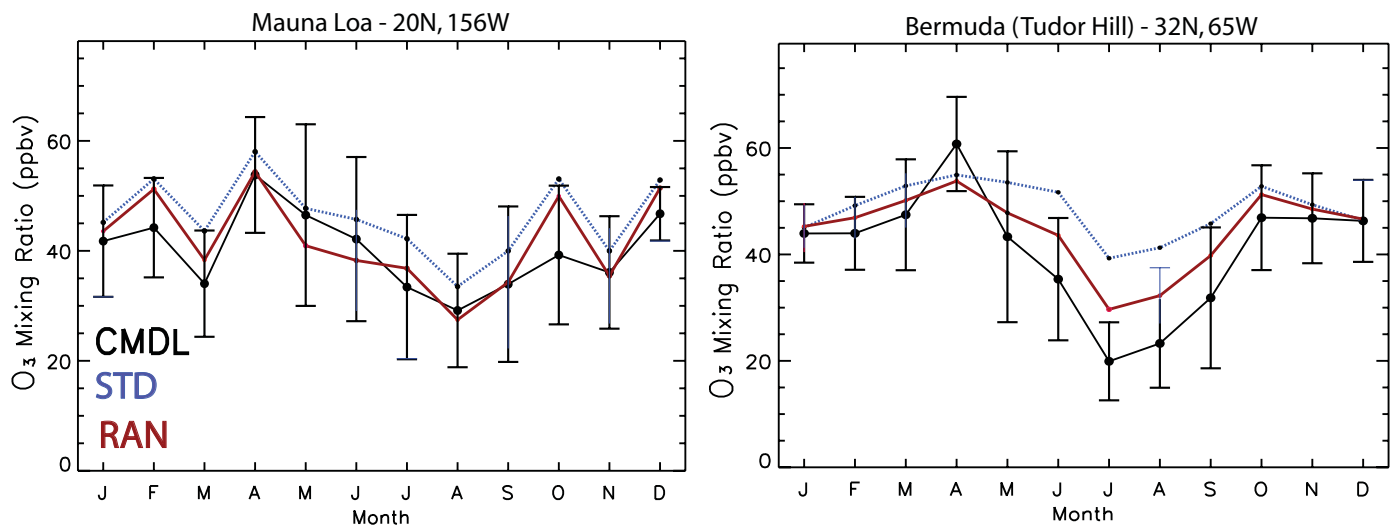

Fig. 7. Ozone model (STD and RAN) - measurement (CMDL) comparisons for Mauna Loa and Bermuda. Error bars indicate the temporal variability of measurements made within each month.

Table 1. Coefficients of Variation (C.V.) for $J\left(\mathrm{O}^{1} \mathrm{D}\right)$, $\mathrm{OH}$ and ozone. Values are shown for Weybourne (JAS) and $0^{\circ}-60^{\circ} \mathrm{N}(1 \mathrm{st}$ of July). The updated model (RAN) has greater variability than the standard (STD).

\begin{tabular}{lccc}
\hline \multicolumn{4}{c}{ MODEL VERSION } \\
& STD & AVG & RAN \\
\hline \multicolumn{4}{c}{$1.1^{\circ} E, 52.9^{\circ} N$} \\
C.V. for $J\left(\mathrm{O}^{1} \mathrm{D}\right)(\%)$ & 24.6 & 27.9 & 29.2 \\
C.V. for $\mathrm{OH}(\%)$ & 45.0 & 50.4 & 52.0 \\
C.V. for $\mathrm{O}_{3}(\%)$ & 20.1 & 23.9 & 24.9 \\
$0-360^{\circ} E$, & $0-60^{\circ}$ & $N$ \\
C.V. for $J\left(\mathrm{O}^{1} \mathrm{D}\right)(\%)$ & 23.0 & 33.5 & 35.2 \\
C.V. for $\mathrm{OH}^{(\%)}$ & 50.2 & 63.8 & 63.8 \\
C.V. for $\mathrm{O}_{3}(\%)$ & 34.6 & 40.8 & 41.1 \\
\hline
\end{tabular}

Table 1 shows the coefficient of variation (C.V.) for three inter-related variables, $J\left(\mathrm{O}^{1} \mathrm{D}\right), \mathrm{OH}$ and ozone for the two cases described above. C.V. is a normalized measure of dispersion of a probability distribution, defined as the ratio of the standard deviation to the mean. STD uses a climatological cloudiness. In order to determine if differences between STD and RAN are due to this, the model was also ran using Fast-JX but replacing the six-hourly cloud input in RAN with seasonal mean data (still with a 3-D space variability). This run was tagged as AVG.

For all variables, even for ozone with its more complex chemistry, the variation is significantly greater for the run with Fast-JX (RAN) than with the standard scheme (STD). Furthermore, the differences between STD and RAN cannot be explained by just fixing the cloudiness to seasonal values. This is even more evident in the lower part of the table $\left(0^{\circ}-60^{\circ} \mathrm{N}\right)$ and implies that the inability of the standard scheme to reproduce the high levels of variation is caused not just because of the poor seasonally variable clouds in the Cambridge 2D-Model (which produces the look-up table), but also because of the two-dimensional (zonal) nature of the latter model itself. Differences in the representation of the temperature dependence of photolysis rates in the two model 
versions may also have some influence but it is expected to be a less important factor in this case.

\subsection{Comparisons to measurements}

For the evaluation of p-TOMCAT performance using the Fast-JX photolysis code, the model output was compared to a variety of observational data. Improvements in global model performance when upgrading to a new-generation photolysis code have not been discussed by comparing to measurement data in previous papers.

Flask CO measurements collected from the CMDL (now NOAA-ESRL-GMD) network (see Novelli et al. (2003) for details), surface ozone measurements from the same network (see Oltmans and Levy II (1994)) and ozonesonde data from WOUDC (http://www.woudc.org/) were used in a similar way as in the model validation study for the European project RETRO (Schultz, 2007a), in which p-TOMCAT was one of the contributing models. The altitude of each station has been taken into account for the sampling of model values. The year of study is 1997 (both model output and measurements), a standard validation year for p-TOMCAT experiments.

Table 2 shows annual mean biases and the correlation coefficients for $\mathrm{CO}$ calculated from the monthly mean values for 36 out of the 42 sites analyzed by RETRO. The stations excluded were those with more than two months of missing data. In this table we present the overall picture for three latitude bands: the tropics, the southern extratropics and the northern extratropics. The biases provide information on how well the model can simulate the levels of the tracer on average and the correlation coefficients show how well the seasonal cycle is captured.

It is clear that both versions of the model perform better in the Southern Hemisphere than in the northern. Northern hemispheric CO, whose concentration is heavily influenced by anthropogenic emissions, has proved to be difficult to model correctly by most present-day models (Shindell et al., 2006) and these systematic model discrepancies have been attributed to a significant underestimation of the current anthropogenic emissions. The model bias becomes larger when using Fast-JX (RAN) rather than the standard photolysis scheme (STD), which may be related to the higher $J\left(\mathrm{O}^{1} \mathrm{D}\right)$ values found in Sect. 3.2. Higher concentrations of $\mathrm{O}^{1} \mathrm{D}$ lead to higher $\mathrm{OH}$ concentrations and, thus, more effective $\mathrm{CO}$ oxidation (removal). Although the absolute bias increases, the correlation coefficient improves significantly (from 0.48 to 0.70 ) when using Fast-JX. This is related to the fact that the time variability in cloudiness is better captured in the new version of the model (see Sect. 4.1) which affects the seasonal variability in the concentrations of $\mathrm{CO}$.

Two typical sites, one in the northern (Mace Head) and one in the Southern Hemisphere (Palmer Station) are shown in Fig. 6. It is clear how well the updated version of the model captures both the levels of $\mathrm{CO}$ and its seasonal cycle in the SH. The performance is not as good for the NH site.
The plot supports the contention that model anthropogenic emissions are too low in the Northern Hemisphere and this is the cause of the discrepances between the model and the measurements. Thus, the larger bias seen when using Fast-J is not very significant and performance was probably better for the wrong reasons in the past: less accurate photolysis was causing biases which were compensated for by the low emissions. On the other hand, we still see an improvement in catpuring the seasonal cycle when using Fast-JX (correlation coefficient increases from 0.59 to 0.76 for this location).

In a similar way, surface ozone data for Bermuda, Barrow, Mauna Loa, Niwot Ridge, Samoa and South Pole have been used to assess model performance. The measurements are hourly so only the 00:00, 06:00, 12:00, 18:00 UT values have been used in the analysis to coincide with the model output.

Table 3 shows that the use of Fast-JX has improved the model simulation of surface ozone. Both the bias has been reduced (from $6.59 \mathrm{ppbv}$ to $4.07 \mathrm{ppbv}$ ), and the correlation coefficient has been increased (from 0.65 to 0.70 ). The station for which the model still performs poorly is Barrow ( $157 \mathrm{~W}$, $71 \mathrm{~N}$ ). This is very likely to be a result of the lack of halogen chemistry in the CTM, which results in the calculated values of ozone being much higher than the observations, especially in spring (Barrie et al., 2006). However, this feature is common among most of the models examining ozone chemistry at this location and is not related to the photolysis treatment.

It is interesting to note that the stations which lie in or close to the tropics (BMW, MLO, SMO) are those with the most significant improvement when changing the photolysis scheme (except from the correlation for MLO). This is probably because cloud presence in these areas is associated with large optical depths and thus with intense modification of the radiation field, which needs to be captured correctly.

In Fig. 7 we also show plots of the seasonal variation of ozone for two of the stations with no missing months of data. It is clear that the way that the seasonal cycle is being captured significantly improves when using Fast-JX instead of the standard photolysis scheme for these two tropical and subtropical stations.

Table 4 shows how the two model versions perform when their results are compared to ozonesonde data. The average bias at 850 and $500 \mathrm{hPa}$ is smaller when using Fast-JX (RAN) instead of the standard photolysis scheme. This is consistent with what was found for the surface sites (Table 3). The bias remains high in the upper troposphere $(300 \mathrm{hPa})$, a feature which we believe is not related to the treatment of photolysis. The correlation coefficient clearly improves for all altitudes, so overall there is an improvement with the use of Fast-JX.

\subsection{Effect of clouds on the global abundances of tracers}

In this subsection, as part of our evaluation process, we examine how the upgraded p-TOMCAT captures the global effects of clouds in composition. 
Table 2. p-TOMCAT surface CO annual mean biases and correlation coefficients with CMDL flask measurements based on monthly means from 36 sites. The model versions examined are that using the standard photolysis scheme (STD) and that using Fast-JX with the approximate random overlap assumption (RAN).

\begin{tabular}{lrrrr}
\hline & $\begin{array}{r}\text { CO bias } \\
(\text { ppbv })\end{array}$ & $\begin{array}{r}\text { CO bias } \\
(\mathrm{ppbv})\end{array}$ & $\begin{array}{r}\text { CO correl. } \\
\text { coef. }\end{array}$ & $\begin{array}{r}\text { CO correl. } \\
\text { coef. }\end{array}$ \\
& STD & RAN & STD & RAN \\
\hline Southern Extratropics (90 S, 20 S) & +10.73 & -0.79 & 0.73 & 0.94 \\
Tropics (20 S, 20 N) & -11.02 & -22.70 & 0.60 & 0.79 \\
Northern Extratropics (20 N, 90 N) & -33.30 & -49.45 & 0.40 & 0.61 \\
Mean & -23.46 & -38.10 & 0.48 & 0.70 \\
\hline
\end{tabular}

Table 3. p-TOMCAT surface ozone annual mean biases and correlation coefficients with CMDL measurements based on monthly means for 6 CMDL surface sites. The model versions examined are that using the standard photolysis scheme (STD) and that using Fast-JX employing the approximate random overlap assumption (RAN).

\begin{tabular}{llllll}
\hline & $\begin{array}{l}\mathrm{O}_{3} \mathrm{Abs} . \\
(\mathrm{ppbv})\end{array}$ & $\begin{array}{l}\mathrm{O}_{3} \text { bias } \\
(\mathrm{ppbv})\end{array}$ & $\begin{array}{l}\mathrm{O}_{3} \text { bias } \\
(\mathrm{ppbv})\end{array}$ & $\begin{array}{l}\mathrm{O}_{3} \text { correl. } \\
\text { coef. }\end{array}$ & $\begin{array}{l}\mathrm{O}_{3} \text { correl. } \\
\text { coef. }\end{array}$ \\
Stations & $\mathrm{CMDL}$ & $\mathrm{STD}$ & $\mathrm{RAN}$ & $\mathrm{STD}$ & $\mathrm{RAN}$ \\
\hline $\mathrm{BMW}\left(65^{\circ} \mathrm{W}, 32^{\circ} \mathrm{N}\right)$ & 40.82 & 7.69 & 3.82 & +0.81 & +0.97 \\
$\mathrm{BRW}\left(157^{\circ} \mathrm{W}, 71^{\circ} \mathrm{N}\right)$ & 24.90 & 2.94 & 3.01 & -0.11 & -0.02 \\
$\mathrm{MLO}\left(156^{\circ} \mathrm{W}, 20^{\circ} \mathrm{N}\right)$ & 40.09 & 6.17 & 1.76 & +0.88 & +0.84 \\
$\mathrm{NWR}\left(106^{\circ} \mathrm{W}, 40^{\circ} \mathrm{N}\right)$ & 48.62 & 3.77 & 3.57 & +0.64 & +0.65 \\
$\mathrm{SMO}\left(171^{\circ} \mathrm{W}, 14^{\circ} \mathrm{S}\right)$ & 14.22 & 14.00 & 8.27 & +0.83 & +0.96 \\
$\mathrm{SPO}\left(25^{\circ} \mathrm{W} 90^{\circ} \mathrm{S}\right)$ & 26.46 & 4.97 & 4.02 & +0.88 & +0.83 \\
$\mathrm{Mean}$ & & 6.59 & 4.07 & +0.65 & +0.70 \\
\hline
\end{tabular}

In Table 5, the influence of clouds on ozone, $\mathrm{NO}_{\mathrm{x}}$ and $\mathrm{CO}$ burdens, as well as on the concentration of $\mathrm{OH}$ and the lifetime of methane, is shown by subtracting the values calculated with a cloud-free atmosphere from the values calculated for each cloud treatment (AVG, RAN, LIN). AVG represents the run using the seasonal mean cloudiness (mentioned in Sect. 4.1). LIN is the common cloud handling employed by many CTMs, which assumes that a cloud covers the entire horizontal grid and its optical depth is averaged over the clear and cloudy areas of the grid. Finally, RAN represents the approximate random overlap scheme. The $\mathrm{OH}$ global mean concentration is mass weighted, as described by Lawrence et al. (2001). All the results in Table 5 are annual and global averages/totals.

First, the global $\mathrm{OH}$ concentration generally increases when taking clouds into account, consistent with previous studies. As also found by Liu et al. (2006a), the global effect is small, due to fact that above cloud increases in $\mathrm{OH}$ cancel out with below cloud decreases. The largest, though modest $(2.5 \%)$, increase is found when the AVG or the LIN cloud handling is used. LIN and AVG usually overestimate optical depths, thus enhancing the effect of clouds. These results for $\mathrm{OH}$ are closer to Liu et al. (2006a), who used Fast-J, rather to Tie et al. (2003b) who found a much larger effect on OH (80-88\% for LIN) using FTUV. On the other hand, the lifetime of methane increases, despite the increase of $\mathrm{OH}$ concentrations. This is because this measure is more sensitive to changes in $\mathrm{OH}$ concentrations near the surface (Liu et al., 2006a). Temperatures, which strongly affect the oxidation rate of methane, are higher at the lower parts of the atmosphere and thus a change in $\mathrm{OH}$ concentrations at low altitudes will have a larger impact on global methane as compared to a change at high altitudes. Furthermore, the global effect is weighted more towards the surface since this is where most of the molecules available for reaction exist. The global CO burden generally decreases for AVG or LIN when adding clouds, but it increases slightly when using RAN.

Finally, $\mathrm{NO}_{\mathrm{x}}$ and ozone burdens increase when clouds are added, however this effect is quite modest when using RAN. Consistent with Liu et al. (2006a), the majority of global changes remain small when adding clouds, especially with 
Table 4. p-TOMCAT ozone annual mean biases and correlation coefficients with WOUDC sonde measurements based on monthly means from 10 WOUDC sites. The model versions examined are that using the standard photolysis scheme (STD) and that using Fast-JX employing the approximate random overlap assumption (RAN).

\begin{tabular}{lllll}
\hline & $\begin{array}{l}\mathrm{O}_{3} \text { bias } \\
(\text { ppbv })\end{array}$ & $\begin{array}{l}\mathrm{O}_{3} \text { bias } \\
(\text { ppbv })\end{array}$ & $\begin{array}{l}\mathrm{O}_{3} \text { correl. } \\
\text { coef. }\end{array}$ & $\begin{array}{l}\mathrm{O}_{3} \text { correl. } \\
\text { coef. }\end{array}$ \\
& $\mathrm{STD}$ & $\mathrm{RAN}$ & $\mathrm{STD}$ & $\mathrm{RAN}$ \\
\hline $850 \mathrm{hPa}$ & 5.41 & 4.36 & -0.13 & 0.56 \\
$500 \mathrm{hPa}$ & 12.06 & 10.94 & 0.32 & 0.53 \\
$300 \mathrm{hPa}$ & 42.23 & 44.47 & 0.28 & 0.49 \\
Mean & 19.90 & 19.91 & 0.15 & 0.53 \\
\hline
\end{tabular}

Table 5. Changes in tropospheric burdens of $\mathrm{CO}, \mathrm{NO}_{\mathrm{x}}$, ozone, $\mathrm{OH}$ tropospheric mean concentrations and methane lifetimes when using clouds (cloudy minus clear-sky). AVG is the run using seasonal mean cloudiness, LIN is with the common cloud handling not accounting for cloud overlap and RAN represents the results from the model run using the approximate random overlap assumption.

\begin{tabular}{llllll}
\hline & $\begin{array}{l}\text { OH Mean Conc. } \\
(\%)\end{array}$ & $\begin{array}{l}\mathrm{CH}_{4} \text { Lifetime } \\
(\%)\end{array}$ & $\begin{array}{l}\mathrm{CO} \text { Burden } \\
(\%)\end{array}$ & $\begin{array}{l}\mathrm{NO}_{\mathrm{x}} \text { Burden } \\
(\%)\end{array}$ & $\begin{array}{l}\mathrm{O}_{3} \text { Burden } \\
(\%)\end{array}$ \\
\hline AVG & +2.50 & +2.18 & -0.61 & +10.2 & +3.18 \\
LIN & +2.47 & +1.27 & -1.07 & +7.58 & +3.12 \\
RAN & +0.87 & +0.34 & +0.76 & +2.62 & +1.24 \\
\hline
\end{tabular}

the use of RAN, which is claimed to be the most appropriate method among those used in this study (Liu et al., 2006a).

We need to add here, that the tropospheric ozone burden in the new model version (using Fast-JX) is $298 \mathrm{Tg}$, which is an improved value in respect to the average reported by Stevenson et al. (2006) $(344 \pm 39 \mathrm{Tg})$ when compared to what it was in p-TOMCAT at the time of that study $(247 \mathrm{Tg})$. The full methane lifetime is now around 7 years, which is close to the low end of the ACCENT range (it used to be an outlier with a too high lifetime $-12.5 \mathrm{yrs}$ ). We expect that the inclusion of aerosols in the radiative transfer calculations, the use of more realistic $\mathrm{CO}$ emissions and of a more upto-date methane field, could increase the methane lifetime in the model and bring it even closer to the values estimated from average present-day models.

\section{Conclusions}

We have presented and validated the updated version of the p-TOMCAT CTM using the Fast-JX photolysis code. First, a one-dimensional offline test showed that Fast-JX is capable of capturing the above and in-cloud enhancement of photolysis rates as well as the enhancements caused by internal reflections between overlying cloud layers. The code was then validated offline against observations and was shown to capture the variability in photolysis rates much better than the standard scheme used in p-TOMCAT, whose 2-dimensional structure and seasonally varying cloud representation, make it out-of-date with current model developments. The improvements are evident both for the surface and for higher altitudes.

By studying the PDFs and coefficients of variation of $J\left(\mathrm{NO}_{2}\right), J\left(\mathrm{O}^{1} \mathrm{D}\right), \mathrm{OH}$ and ozone as calculated in the standard and the new CTM version, it is clear that Fast-JX is effective in making the model more capable of capturing values with a broader range, both when examining its performance in time and in space. The seasonally averaged cloudiness used in the standard scheme is not the only factor reducing its output range, but other factors like the zonal mean nature (2D-Model) of the standard code may be equally or more important.

The general performance of p-TOMCAT against tracer measurements (ozone, $\mathrm{CO}$ ) is good, with some strong improvements in the way that the CTM captures the levels and the seasonal cycles of tracers when using Fast-JX and sixhourly cloud data (correlation coefficients mostly between 0.50 and 0.95 ). CO concentrations remain underestimated in the new model version but this is mainly attributed to too low surface emissions, as is the case with many present-day CTMs. We expect improvements when using more realistic emissions and when including aerosols (especially black carbon) in the radiative transfer calculations, which attenuate radiation and thus reduce surface $\mathrm{OH}$ and $\mathrm{CO}$ removal rates. 
Finally, the way that clouds and different cloud handling treatments affect global mean photolysis rates and species abundances in the model is generally in good agreement with Liu et al. (2006a): clouds have a modest global mean effect, less than $\pm 3 \%$ for all species examined.

The detailed effect of clouds and other factors affecting photolysis rates on global and regional ozone budgets will be the focus of a future study using the model version evaluated here.

Acknowledgements. The lead author wishes to thank NERC (UK) and IKY (Greece) for funding. Also, the authors thank Paul Berrisford for providing the ECMWF data and Christoph Gerbig for providing the ACSOE data.

Edited by: V. Grewe

\section{References}

Atkinson, R. A., Baulch, D. L., Cox, R. A., Crowley, J. N., Hampson Jr., R. F., Hynes, R. G., Jenkin, M. E., Kerr, J. A., Rossi, M. J., and Troe, J.: Summary of evaluated kinetic and photochemical data for atmospheric chemistry, http://www. iupac-kinetic.ch.cam.ac.uk/, web version, 2005.

Barnard, J. C., Chapman, E. G., Fast, J. D., Schmelzer, J. R., Slusser, J. R., and Shetter, R. E.: An evaluation of the FAST-J photolysis algorithm for predicting nitrogen dioxide photolysis rates under clear and cloudy sky conditions, Atmos. Environ., 38, 3393-3403, doi:10.1016/j.atmosenv.2004.03.034, 2004.

Barrie, L. A., Bottenheim, J. W., Schnell, R. C., Crutzen, P. J., and Rasmussen, R. A.: Ozone destruction and photochemical reactions at polar sunrise in the lower Arctic atmosphere, Nature, 334, 138-141, doi:10.1038/334138a0, 2006.

Bohn, B., Corlett, G. K., Gillmann, M., Sanghavi, S., Stange, G., Tensing, E., Vrekoussis, M., Bloss, W. J., Clapp, L. J., Kortner, M., Dorn, H.-P., Monks, P. S., Platt, U., Plass-Dülmer, C., Mihalopoulos, N., Heard, D. E., Clemitshaw, K. C., Meixner, F. X., Prevot, A. S. H., and Schmitt, R.: Photolysis frequency measurement techniques: results of a comparison within the ACCENT project, Atmos. Chem. Phys., 8, 5373-5391, 2008,

http://www.atmos-chem-phys.net/8/5373/2008/.

Briegleb, B. P.: Delta-eddington approximation for solar-radiation in the NCAR community climate model, J. Geophys. Res., 97, 7603-7612, 1992.

Carver, G. D. and Stott, P. A.: IMPACT: An implicit time integration scheme for chemical species and families, Ann. Geophys., 18, 337-346, doi:10.1007/s00585-000-0337-y, 1999.

Carver, G. D., Brown, P. D., and Wild, O.: The ASAD atmospheric chemistry integration package and chemical reaction database, Comput. Phys. Commun., 105, 197-215, 1997.

Chandrasekhar, S.: Radiative Transfer, Dover, New York, 1960.

Chin, M., Ginoux, P., Kinne, S., Torres, O., Holben, B. N., Duncan, B. N., Martin, R. V., Logan, J. A., Higurashi, A., and Nakajima, T.: Tropospheric aerosol optical thickness from the GOCART model and comparisons with satellite and Sun photometer measurements, J. Atmos. Sci., 59, 461-483, 2002.

Crawford, J., Shetter, R. E., Lefer, B., Cantrell, C., Junkermann, W., Madronich, S., and Calvert, J.: Cloud impacts on UV spectral ac- tinic flux observed during the International Photolysis Frequency Measurement and Model Intercomparison (IPMMI), J. Geophys. Res., 108(D16), 8545, doi:10.1029/2002JD002731, 2003.

Del Genio, A. D., Yao, M. S., Kovari, W., and Lo, K. K. W.: A prognostic cloud water parameterization for global climate models, J. Climate, 9, 270-304, 1996.

Evans, M. J. and Jacob, D. J.: Impact of new laboratory studies of $\mathrm{N}_{2} \mathrm{O}_{5}$ hydrolysis on global model budgets of tropospheric nitrogen oxides, ozone and OH, Geophys. Res. Lett., 32, L09813, doi:10.1029/2005GL022469, 2005.

Feng, Y., Penner, J. E., Sillman, S., and Liu, X. H.: Effects of cloud overlap in photochemical models, J. Geophys. Res., 109, D04310, doi:10.1029/2003JD004040, 2004.

Giannakopoulos, C., Chipperfield, M. P., Law, K. S., and Pyle, J. A.: Validation and intercomparison of wet and dry deposition schemes using $\mathrm{Pb}-210$ in a global three-dimensional off-line chemical transport model, J. Geophys. Res., 104, 23761-23784, 1999.

Holtslag, A. A. M. and Boville, B. A.: Local versus nonlocal boundary-layer diffusion in a global climate model, J. Climate, 6, 1825-1842, 1993.

Hough, A. M.: The calculation of photolysis rates for use in global modelling studies, Tech. rep., UK Atomic Energy Authority, Harwell, Oxon., UK, 1988.

Lathière, J., Hauglustaine, D. A., Friends, A. D., De NobletDucoudré, N., Viovy, N., and Folberth, G. A.: Impact of climate variability and land use changes on global biogenic volatile organic compound emissions, Atmos. Chem. Phys., 6, 2129-2146, 2006, http://www.atmos-chem-phys.net/6/2129/2006/.

Law, K. S. and Pyle, J. A.: Modeling trace gas budgets in the troposphere 1. Ozone and odd nitrogen, J. Geophys. Res., 98, 1837718400, 1993.

Law, K. S., Plantevin, P. H., Shallcross, D. E., Rogers, H. J., Pyle, J. A., Grouhel, C., Thouret, V., and Marenco, A.: Evaluation of modeled $\mathrm{O}_{3}$ using Measurement of Ozone by Airbus In-Service Aircraft (MOZAIC) data, J. Geophys. Res., 103, 25721-25737, 1998.

Lawrence, M. G., Jöckel, P., and von Kulhmann, R.: What does the global mean $\mathrm{OH}$ concentration tell us?, Atmos. Chem. Phys., 1, 37-49, 2001, http://www.atmos-chem-phys.net/1/37/2001/.

Lefer, B. L., Shetter, R. E., Hall, S. R., Crawford, J. H., and Olson, J. R.: Impact of clouds and aerosols on photolysis frequencies and photochemistry during TRACE-P: 1 . Analysis using radiative transfer and photochemical box models, J. Geophys. Res., 108(D21), 8821, doi:10.1029/2002JD003171, 2003.

Liao, H., Yung, Y. L., and Seinfeld, J. H.: Effects of aerosols on tropospheric photolysis rates in clear and cloudy atmospheres, J. Geophys. Res., 104(D19), 23697-23707, 1999.

Liu, H., Crawford, J. H., Pierce, R. B., Norris, P., Platnick, S. E., Chen, G., Logan, J. A., Yantosca, R. M., Evans, M. J., Kittaka, C., Feng, Y., and Tie, X.: Radiative effect of clouds on tropospheric chemistry in a global three-dimensional chemical transport model, J. Geophys. Res., 111, D20303, doi:10.1029/ 2005JD006403, 2006a.

Liu, J., Drummond, J. R., Jones, D. B. A., Cao, Z., Bremer, H., Kar, J., Zou, J., Nichitiu, F., and Gille, J. C.: Large horizontal gradients in atmospheric $\mathrm{CO}$ at the synoptic scale as seen by spaceborne Measurements of Pollution in the Troposphere, J. Geophys. Res., 111, D02306, doi:10.1029/2005JD006076, http:// 
www.agu.org/pubs/crossref/2006/2005JD006076.shtml, 2006b.

Madronich, S.: Photodissociation in the Atmosphere 1. Actinic Flux and the Effects of Ground Reflections and Clouds, J. Geophys. Res., 92, 9740-9752, 1987.

Matthijsen, J., Suhre, K., Rosset, R., Eisele, F. L., Mauldin, R. L., and Tanner, D. J.: Photodissociation and UV radiative transfer in a cloudy atmosphere: Modeling and measurements, J. Geophys. Res., 103(D13), 16665-16676, 1998.

Monks, P. S., Rickard, A. R., Hall, S. L., and Richards, N. A. D.: Attenuation of spectral actinic flux and photolysis frequencies at the surface through homogenous cloud fields, J. Geophys. Res., 109(D17), D17206, doi:10.1029/2003JD004076, 2004.

Müller, J.-F.: Geographical distribution and seasonal variation of surface emissions and deposition velocities of atmospheric trace gases, J. Geophys. Res., 97, 3787-3804, 1992.

Neu, J. L., Prather, M. J., and Penner, J. E.: Global atmospheric chemistry: Integrating over fractional cloud cover, J. Geophys. Res., 112, D11306, doi:10.1029/2006JD008007, 2007.

Novelli, P. C., Masarie, K. A., Lang, P. M., Hall, B. D., Myers, R. C., and Elkins, J. W.: Reanalysis of tropospheric CO trends: Effects of the 1997-1998 wildfires, J. Geophys. Res., 108(D15), 4464, doi:10.1029/2002JD003031, 2003.

Oltmans, S. J. and Levy II, H.: Surface ozone measurements from a global network, Atmos. Environ., 28, 9-24, doi:10.1016/ 1352-2310(94)90019-1, 1994.

Pöschl, U., von Kulhmann, R., Poisson, N., and Crutzen, P. J.: Development and intercomparison of condensed isoprene oxidation mechanisms for global atmospheric modelling, J. Atmos. Chem., 37, 29-52, 2000.

Prather, M. J.: Numerical Advection by Conservation of SecondOrder Moments, J. Geophys. Res., 91, 6671-6681, 1986.

Price, C. and Rind, D.: Modeling global lightning distributions in a General Circulation Model, Mon. Weather Rev., 122, 1930-1939, doi:10.1175/1520-0493(1994)122〈1930:MGLDIA〉 2.0.CO;2, 1994.

Pulles, T. and van het Bolscher, M.: Assessment of global emissions from fuel combustion in the final decades of the 20th Century, Application of the Emission Inventory Model TEAM, Tech. rep., R. Brand, and A. Visschedijk, TNO report 2007-A-R0132, Appeldorn, The Netherlands, 2007.

Roelofs, G.-J. and Lelieveld, J.: Distribution and budget of $\mathrm{O}_{3}$ in the troposphere calculated with a chemical general circulation model, J. Geophys. Res., 100, 20983-20998, 1995.

Schultz, M. G.: REanalysis of the TROpospheric chemical composition over the past 40 years, Tech. rep., 5th EU framework programme, 2007a.

Schultz, M. G.: Emission data sets and methodologies for estimating emissions, RETRO deliverable D1-6, Tech. rep., 5th EU framework programme, 2007b.

Schultz, M. G., Heil, A., Hoelzemann, J. J., Spessa, A., Thonicke, K., Goldammer, J. G., Johann, G., Held, A. C., Pereira, J. M. C., and van het Bolscher, M.: Global wildland fire emissions from 1960 to 2000, Glob. Biogeochem. Cy., 22, GB2002, doi:10.1029/ 2007GB003031, 2008.

Shindell, D. T., Faluvegi, G., Stevenson, D. S., Krol, M. C., Emmons, L. K., Lamarque, J.-F., Pétron, G., Dentener, F. J., Ellingsne, K., Schultz, M. G., Wild, O., Amann, M., Atherton, C. S., Bergmann, D. J., Bey, I., Butler, T., Cofala, J., Collins, W. J., Derwent, R. G., Doherty, R. M., Drevet, J., Eskes, H. J.,
Fiore, A. M., Gauss, M., Hauglustaine, D. A., Horowitz, L. W., Isaksen, I. S. A., Lawrence, M. G., Montanaro, V., Müller, J.-F., Pitari, G., Prather, M. J., Pyle, J. A., Rast, S., Rodriguez, J. M., Sanderson, M. G., Savage, N. H., Strahan, S. E., Sudo, K., Szopa, S., Unger, N., van Noije, T. P. C., and Zeng, G.: Multimodel simulations of carbon monoxide: Comparison with observations and projected near-future changes, J. Geophys. Res., 111, D19306, doi:10.1029/2006JD007100, 2006.

Slingo, A. and Schrecker, H. M.: On the shortwave radiative properties of stratiform water clouds., Q. J. Roy. Meteor. Soc., 108, 407-426, 1982.

Stevenson, D. S., Dentener, F. J., Schultz, M. G., Ellingsen, K., van Noije, T. P. C., Wild, O., Zeng, G., Amann, M., Atherton, M., Bell, N., Bergmann, D. J., Bey, I., Bulter, T., Cofala, J., Collins, W. J., Derwent, R. G., Doherty, R. M., Drevet, J., Eskes, H. J., Fiore, A. M., Gauss, M., Hauglustaine, D. A., Horowitz, L. W., Isaksen, I. S. A., Krol, M. C., Lamarque, J.-F., Lawrence, M. G., Montanaro, V., Müller, J. F., Pitari, G., Prather, M. J., Pyle, J. A., Rast, S., Rodriguez, J. M., Sanderson, M. G., Savage, N. H., Shindell, D. T., Strahan, S. E., Sudo, K., and Szopa, S.: Multimodel ensemble simulations of present-day and nearfuture tropospheric ozone, J. Geophys. Res., 111, D08301, doi: 10.1029/2005JD006338, 2006.

Stockwell, D. Z., Giannakopoulos, C., Plantevin, P.-H., Carver, G. D., Chipperfield, M. P., Law, K. S., Pyle, J. A., Shallcross, D. E., and Wang, K. Y.: Modelling $\mathrm{NO}_{x}$ from lightning and its impact on global chemical fields, Atmos. Environ., 33, 44774493, doi:10.1016/S1352-2310(99)00190-9, 1999.

Tie, X. X., Emmons, L., Horowitz, L., Brasseur, G., Ridley, B., Atlas, E., Stround, C., Hess, P., Klonecki, A., Madronich, S., Talbot, R., and Dibb, J.: Effect of sulfate aerosol on tropospheric NOx and ozone budgets: Model simulations and TOPSE evidence, J. Geophys. Res., 108, 8364, doi:10.1029/2001JD001508, 2003a.

Tie, X. X., Madronich, S., Walters, S., Y., Z. R., Rasch, P., and Collins, W.: Effect of clouds on photolysis and oxidants in the troposphere, J. Geophys. Res., 108(D20), 4642, doi:10.1029/2003JD003659, http://www.agu.org/pubs/crossref/ 2003/2003JD003659.shtml, 2003b.

Tiedtke, M.: A Comprehensive Mass Flux Scheme for Cumulus Parameterization in Large-Scale Models, Mon. Weather Rev., 117, 1779-1800, 1989.

Uppala, S. M., Kallberg, P. W., Simmons, A. J., Andrae, U., Bechtold, V. D., Fiorino, M., Gibson, J. K., Haseler, J., Hernandez, A., Kelly, G. A., Li, X., Onogi, K., Saarinen, S., Sokka, N., Allan, R. P., Andersson, E., Arpe, K., Balmaseda, M. A., Beljaars, A. C. M., Van De Berg, L., Bidlot, J., Bormann, N., Caires, S., Chevallier, F., Dethof, A., Dragosavac, M., Fisher, M., Fuentes, M., Hagemann, S., Holm, E., Hoskins, B. J., Isaksen, L., Janssen, P. A. E. M., Jenne, R., McNally, A. P., Mahfouf, J. F., Morcrette, J. J., Rayner, N. A., Saunders, R. W., Simon, P., Sterl, A., Trenberth, K. E., Untch, A., Vasiljevic, D., Viterbo, P., and Woollen, J.: The ERA-40 re-analysis, Q. J. Roy. Meteor. Soc., 131, 29613012, 2005.

Volz-Thomas, A., Lerner, A., Patz, H. W., Schultz, M., McKenna, D. S., Schmitt, R., Madronich, S., and Roth, E. P.: Airborne measurements of the photolysis frequency of $\mathrm{NO}_{2}$, J. Geophys. Res., 101, 18613-18627, 1996. 
Wang, K. Y., Pyle, J. A., Sanderson, M. G., and Bridgeman, C.: Implementation of a convective atmospheric boundary layer scheme in a tropospheric chemistry transport model, J. Geophys. Res., 104, 23729-23745, 1999.

Wild, O., Zhu, X., and Prather, M. J.: Fast-J: Accurate simulation of in- and below-cloud photolysis in Global Chemical Models, J. Atmos. Chem., 37, 245-282, doi:10.1023/A:1006415919030, 2000 .
Yang, H. and Levy, H.: Sensitivity of photodissociation rate coefficients and $\mathrm{O}_{3}$ photochemical tendencies to aerosols and clouds, J. Geophys. Res., 109, D24301, doi:0.1029/2004JD005032, 2004.

Young, P. J., Arneth, A., Schurgers, G., Zeng, G., and Pyle, J. A.: The $\mathrm{CO}_{2}$ inhibition of terrestrial isoprene emission significantly affects future ozone projections, Atmos. Chem. Phys., 9, 2793 2803, 2009, http://www.atmos-chem-phys.net/9/2793/2009/. 